\title{
Early warning of famine: a red herring?
}

\section{By P. Cutler, Department of Human Nutrition, London School of Hygiene and Tropical Medicine, Keppel Street, London $W_{1} C_{1}{ }_{7} H T$}

Over the past year or so, there has been an upsurge in interest both in the analysis of famine and in the design and establishment of improved famine early-warning systems. This has been stimulated principally by public and professional interest, aroused by the media exposure of mass starvation in Ethiopia in late 1984. However, despite this increased interest, which has led to a proliferation of seminars, workshops, books, articles, radio and television programmes, and some tens of millions of dollars being invested in improved data-collection systems (including the collation and interpretation of more satellite imagery, meteorological data, improved crop assessment and socio-economic information), a number of key problems of a conceptual and administrative nature remain.

First, it is important to note that many of the existing early-warning systems are a direct legacy of public concern expressed a decade ago in the wake of the last round of Sahelian famines. In response to these, a 'global early-warning system' was set up, based at the headquarters of the Food and Agriculture Organization in Rome. While the global early-warning system can be criticized for its reliance on highly aggregated information on production and consumption compiled from official sources (Cutler, 1984), it nevertheless delivered timely warnings of exceptional crop failures and declining national food availability over $1983_{3}-84$ in as many as twenty-four African countries. At the same time, the national early-warning systems of some countries, notably in Ethiopia, Botswana and Tanzania, were generating much more detailed information which indicated very disturbing trends; while in other countries governments were compiling hurried assessments of available information to make their own cases for emergency aid. Only in a few countries (notably Sudan) were little or no attempts made by national governments to monitor and respond to the growing drought-induced crisis.

The response from donors over the same period, however, was almost without exception late, inadequate and above all politically conditioned. This has been to a large extent forgotten over 1985-86, when donor agencies have been congratulating themselves on the generally well-managed and exceptionally large-scale relief operations which followed the dramatic television coverage. Some have also been quick to disclaim any tardiness in response. For example, in March 1985, the European Economic Community (EEC) publicity journal, the Courier, 
noted under the subtitle 'The Community reacts instantly and well' that 'The Community, of course, did not wait for the media to cover the situation before it sat up and took notice. ... It was, in fact, in April 1984,6 months before the first television pictures, that the EEC brought in its first emergency plan (of 83 million European Currency Units) (Anon., 1985a). Details of this first emergency plan are given on a country-by-country basis, in terms of both cash and food aid. Ethiopia, by far the worst-affected country, is not on the list of food-aid recipients.

One can find other examples, and I am not singling out the EEC for special attack. Elsewhere, such as through the United Nations' emergency operations newsletters, famine relief operations have been lauded as a success story. For example, the United Nations' Africa Emergency Bulletin of November 1985 mentions the 'extraordinarily effective international relief operation which prevented an almost certain catastrophe' (Anon., $1985 b$ ), again referring principally to the post-1984 emergency blitz.

Nevertheless, the agencies have been quick to argue that they were unaware of the true extent of the crisis, particularly in Ethiopia, because of the lack of information. This confusion has been well documented in Peter Gill's (1986) recent book, $A$ Year in the Death of Africa. Essentially, Gill (1986) argues that the major donors preferred to believe the broad estimates of the United Nations' assessment teams sent to compile information about levels of food production and consumption needs in Ethiopia; as against the quite detailed, and in the event reasonably accurate, estimates of the Ethiopian government's Relief and Rehabilitation Commission. The United Nations' assessments were apparently based on four erroneous assumptions: (I) that relief requirements can be assessed by dividing total food supply by the total population; (2) that food surpluses available within the country will be used to feed impoverished famine victims; (3) that food aid flows should be determined by the apparent handling capacity of existing transport infrastructure; (4) that food aid flows are open-ended and will be diverted from existing projects to famine relief.

Being wrong on all counts, the faulty assessment has in turn been blamed on faulty and contradictory information. The information system must therefore be improved, and great efforts are now being made to inject cash, expertise and materials into the Relief and Rehabilitation Commission and into the Central Statistical Office in Ethiopia. It is considered that the latter organization should be supported on the grounds that some information emanating from different departments of government is contradictory, and should be double-checked, and the contradictions accounted for. Elsewhere, as for example in Mali, early-warning initiatives are being supported by as many as eight separate agencies, all of which are attempting to co-ordinate their activities, although this is slow getting-off the ground.

There are several reasons why improving early warning in the current administrative context might be considered as a 'red herring'. In the first place, there has not to my knowledge been any serious discussion among the donor agencies as to what indicators will be taken as a basis for concrete action, and what 
kind of extraordinary response will be possible at an early stage in the famine process.

In the second place, there do not appear to have been attempts made to direct contingency resources to representatives of donor agencies working in famine-prone countries or to give them the administrative leeway to enable them to begin pre-emptive relief operations. This is necessary because bureaucracies do not encourage risk-taking, and are instead likely to penalize individuals who attempt to cut existing red tape. A distinctive feature of the famine conditions of 1983-84 was the rash of assessment missions despatched from head offices months after requests for assistance had been received from branch offices. In such cases, where emergencies were developing rapidly, the terms of reference of the missions had become hopelessly outdated by the time of their eventual arrival.

In the third place, the projects currently being funded are either budgeted for only 2-3 years, or have completely uncertain budgets. In the fourth place, there has been little effort made to secure programme aid to cover essential public expenditures by governments funding long-term early-warning and relief systems. Thus it seems that the improvement of information systems has been in response to short-term political pressure. Western governments can be seen to be doing something about famine without having to make a long-term commitment.

Unless administrative reforms are made, the extent to which we can expect a quicker response to the next major famine seems to depend on its timing. If another decade passes before mass migration and mass starvation become overwhelmingly obvious and unconcealable, then the information systems supported by short-term projects will quite probably have foundered through lack of regular financial support. If, on the other hand, famine erupts over the next $3^{-4}$ years, we may see quicker results from governments and agencies nervous of being exposed as incompetent and tardy so soon after the last display of international inertia.

There is no doubt that improved famine early-warning and monitoring systems are necessary in many cases. It is as important to know when to stop the aid juggernaut as it is to know when to start it. This is notably the case today in Sudan, where bumper harvests have coincided with oversupply of food aid, leading to depressed producer prices and labour shortages in agriculture. Equally, it is far more effective to integrate information and response systems, such as through the provision of permanent works schemes which can be expanded to meet extra demand, than to attempt to set up relief schemes from scratch. However, we seem to be quite a long way from such tried and tested systems (for example, the South Asian experience) in many sub-Saharan countries. For the moment, we can perhaps hope that the agents of improved early-warning systems will be able to make a stronger and more coherent case to the powerful donor agencies and their political patrons. At worst, the systems are likely to become ends in themselves, rather than effective means of famine prevention. 
REFERENCES

Anon. (1985a). Courier, March.

Anon. (1985b). Africa Emergency Bulletin, November.

Cutler, P. (1984). Food Policy 9(3), I89-1 92.

Gill, P. (1986). A Year in the Death of Africa: Politics, Bureaucracy and the Famine. London: Paladin. 